\title{
MENINGKATKAN HASIL BELAJAR SISWA MENGGUNAKAN MODEL QUANTUM TEACHING DENGAN PENDEKATAN KONTEKSTUAL POKOK BAHASAN PECAHAN DI KELAS $V$ TUNARUNGU SDLB NEGERI SUNGAI PARING MARTAPURA
}

\author{
Purwanti
}

\begin{abstract}
Abstrak
Matematika merupakan salah satu mata pelajaran yang diajarkan pada setiap jenjang pendidikan dan mempunyai peranan sangat penting dalam perkembangan ilmu pengetahuan dan teknologi. Namun sering dianggap oleh siswa sebagai mata pelajaran yang sulit untuk dipahami penerapannya, baik teori maupun konsep-konsepnya. Tujuan penelitian ini adalah untuk mengetahui: (1) peningkatan aktivitas belajar siswa kelas V SDLBN Sungai Paring Martapura dalam pembelajaran pecahan menggunakan model quantum teaching dengan pendekatan kontekstual, (2) hasil belajar siswa kelas V SDLBN Sungai Paring dalam pembelajaran pecahan menggunakan model quantum teaching dengan pendekatan kontekstual, dan (3) partisipasi siswa kelas $V$ SDLBN Sungai Paring terhadap penggunaan model quantum teaching dengan pendekatan kontekstual pada pembelajaran pecahan.

Metode yang digunakan dalam penelitian ini adalah penelitian tindakan kelas yang dilaksanakan dalam dua siklus. Penelitian dilaksanakan di SDLBN Sungai Paring Martapura tahun pelajaran 2015-2016. Subjek penelitian ini adalah siswa kelas V SDLBN Sungai Paring dengan jumlah 5 siswa dengan objek penelitian adalah pembelajaran matematika dengan menggunakan model quantum teaching dengan pendekatan kontekstual pada pecahan. Teknik pengumpulan data yang digunakan adalah observasi dan tes.

Hasil Penelitian menunjukkan bahwa: (1) penggunaan model quantum teaching dengan pendekatan kontekstual dapat meningkatkan aktivitas belajar siswa dengan kategori baik sekali, (2) penggunaan model quantum teaching dengan pendekatan kontekstual dapat meningkatkan hasil belajar siswa dengan kategori baik sekali, dan (3) partisisipasi siswa baik terhadap penggunaan model quantum teaching dengan pendekatan kontekstual.
\end{abstract}

Kata Kunci: pecahan, quantum teaching, pendekatan kontekstual, hasil belajar 


\section{Pendahuluan}

Sekolah Dasar Luar Biasa (SDLB) merupakan jenjang pendidikan tingkat dasar yang secara khusus melayani peserta didik yang memiliki tingkat kesulitan dalam mengikuti proses pembelajaran karena kelainan fisik, emosional, mental, sosial, dan/atau memiliki potensi kecerdasan dan bakat istimewa. Pendidikan Luar Biasa bertujuan membantu siswa yang menyandang kelainan fisik, emosional, mental, sosial, kecerdasan dan bakat, agar mampu mengembangkan sikap, kemampuan dan ketrampilan sebagai pribadi maupun anggota masyarakat dalam mengadakan hubungan timbal balik dengan lingkungan sosial, budaya, dan alam sekitar, serta dapat mengembangkan kemampuan dalam dunia kerja atau mengikuti pendidikan lanjutan. (Ekodjatmiko, 2006:7)

Matematika sebagai salah satu mata pelajaran yang diajarkan di sekolah pada jenjang pendidikan dasar, pendidikan menengah dan pendidikan tinggi memegang peranan penting. Berhasil tidaknya pencapaian dari tujuan pembelajaran matematika banyak bergantung pada proses belajar mengajar yang dialami siswa sebagai peserta didik dan guru sebagai pendidik. Salah satu indikasi terjadinya peningkatan kualitas belajar dan tercapainya tujuan pembelajaran dapat dilihat dari adanya peningkatan prestasi akademik siswa secara keseluruhan, mulai dari jenjang pendidikan dasar sampai dengan pendidikan tinggi. Salah satu cara yang dapat dilakukan untuk meningkatkan kualitas belajar siswa adalah dengan menerapkan model pembelajaran yang tepat (Aisyah, 2007).

"Siswa tunarungu adalah seseorang yang mengalami kekurangan atau kehilangan kemampuan mendengar baik sebagian atau seluruhnya yang diakibatkan karena tidak berfungsinya sebagian atau seluruhnya alat pendengaran, sehingga ia tidak dapat menggunakan alat pendengarannya dalam kehidupan sehari hari yang membawa dampak terhadap kehidupannya secara kompleks". Oleh karena itu bagi siswa tunarungu harus dibantu dengan bahasa isyarat, agar mereka dapat berkomunikasi, 
Meningkatkan Hasil Belajar Siswa Menggunakan Model Quantum Teaching Dengan Pendekatan Kontekstual Pokok Bahasan Pecahan Di Kelas V Tunarungu SDLB Negeri Sungai Paring Martapura Tahun Pelajaran 2015/2016

baik menerima maupun menyampaikan kepada orang lain. (Somad dan Tati Herawati, 2004).

Kondisi ini akhirnya berdampak pada prestasi siswa, pada semester sebelumnya masih banyak siswa yang belum memenuhi nilai ketuntasan (KKM) yaitu 60,25 Ini dapat dilihat dari hasil ujian tengah semester siswa yang masih rendah, siswa yang tuntas hanya 2 siswa dari 3 siswa dengan rata-rata nilai 60,08. Materi pecahan masih dianggap sulit oleh sebagian siswa, kesulitan yang terjadi terletak pada bilangan pecahan yang berpenyebut tidak sama yaitu siswa masih bingung dalam mengubah pecahan yang berbeda penyebut ke bentuk pecahan lain yang senilai sehingga penyebutnya menjadi sama dan dari pengamatan di SDLBN Sungai Paring Martapura kelas $V$ dalam cara penyampaian guru masih cenderung kurang melibatkan siswa secara aktif dalam proses pembelajaran karena pada proses pembelajaran pecahan, guru lebih banyak menggunakan metode konvensional sehingga akan membawa pembelajaran pada kondisi yang membosankan dan tidak merangsang pola berpikir siswa. Pecahan bukanlah materi yang sukar, tetapi menjadi tidak mudah apabila diberikan secara langsung kepada siswa dengan menggunakan penyampaian secara konseptual saja atau hanya menggunakan metode ceramah.

Untuk mengatasi permasalahan tersebut diperlukan model pembelajaran. Ada banyak model pembelajaran yang berkembang dalam dunia pendidikan, salah satunya adalah model quantum teaching dengan pendekatan kontekstual. Model quantum teaching dengan pendekatan kontekstual dapat mengajak siswa lebih kreatif dengan gaya belajar yang mengacu pada otak kanan dan otak kiri yang menyertakan segala kaitan interaksi yang membuat siswa lebih bersemangat serta terhibur dan perhatiannya akan lebih fokus dalam proses pembelajaran sehingga tidak membuat siswa merasa bosan dan dengan model pembelajaran ini pula siswa akan lebih cepat ingat dan hapal apa yang dipelajari.

Model quantum teaching ini dimulai di Supercamp, sebuah program percepatan yang ditawarkan learning forum yaitu sebuah perusahaan 
pendidikan internasional yang menekankan perkembangan keterampilan akademis dan keterampilan pribadi, hasilnya menunjukan bahwa muridmurid yang mengikuti Supercamp mendapatkan nilai yang lebih baik dan merasa lebih bangga akan diri mereka sendiri. Sehingga, model quantum teaching dengan pendekatan kontekstual ini diharapkan agar bisa menarik perhatian siswa, menyenangkan dan memberikan motivasi untuk belajar matematika dan meningkatkan hasil belajar siswa.

Oleh karena itu, peneliti tertarik untuk melakukan penelitian dengan subjek yang diteliti adalah siswa kelas V SDLBN Sungai Paring Martapura dan dipilihnya model pembelajaran quantum teaching dengan pendekatan kontekstual dikarenakan model tersebut bertujuan untuk menangani perbedaan kemampuan siswa, karena dalam suatu kelas tingkat kemampuan individu siswa pasti berbeda-beda sehingga model quantum teaching dengan pendekatan kontekstual diharapkan cocok diterapkan dalam pembelajaran di kelas.

Berdasarkan uraian permasalahan dari pengamatan yang terjadi dalam pembelajaran matematika. Maka peneliti tertarik untuk mengangkat judul penelitian tentang "Meningkatkan Hasil Belajar Siswa Menggunakan Model Quantum Teaching dengan Pendekatan Kontekstual Pada Pokok Bahasan Pecahan di Kelas V SDLBN Sungai Paring Tahun Pelajaran 2015-2016"

\section{Metode Penelitian}

Penelitian ini dilaksanakan dengan menggunakan rancangan penelitian tindakan kelas (PTK) dan juga merupakan penelitian kolaboratif dengan meminta kerjasama dengan pihak-pihak lain seperti guru, siswa dan orang-orang terkait lainnya. Dalam penelitian tindakan kelas ini menekankan kepada kegiatan (tindakan) dengan mengujicobakan suatu ide ke dalam praktek atau situasi nyata dalam skala mikro, yang diharapkan kegiatan tersebut mampu memperbaiki dan meningkatkan kualitas proses belajar mengajar. Penelitian ini dilakukan dalam 2 siklus dan setiap siklus 
Meningkatkan Hasil Belajar Siswa Menggunakan Model Quantum Teaching Dengan Pendekatan Kontekstual Pokok Bahasan Pecahan Di Kelas V Tunarungu SDLB Negeri Sungai Paring Martapura Tahun Pelajaran 2015/2016

terdiri dari dua kali pertemuan. Diharapkan dalam 2 siklus pembelajaran tersebut, hasil belajar siswa kelas $V$ tunarungu di SDLBN Sungai Paring tahun pelajaran 2015/2016 dapat ditingkatkan.

Penelitian ini dilaksanakan pada semester II yaitu antara bulan Februari 2016 sampai bulan April 2016 pada tahun pelajaran 2015/2016. Tempat penelitian tindakan kelas ini dilakukan di Sekolah Dasar Luar Biasa Bagian Tunarungu SDLB Negeri Sungai Paring. Pemilihan tempat tersebut didasarkan pada pertimbangan sebagai berikut :

a. SDLB Negeri Sungai Paring Martapura merupakan tempat tugas mengajar bagi peneliti.

b. Untuk memasukkan unsur-unsur pembaruan dalam system pembelajaran anak tunarungu di SDLB Negeri Sungai Paring Martapura.

c. Untuk meningkatkan profesionalitas guru di SDLB Negeri Sungai Paring Martapura.

d. Subjek dalam penelitian ini adalah siswa tunarungu kelas V SDLB Negeri Sungai Paring Martapura yang berjumlah 5 orang siswa lakilaki.

e. Objek penelitian ini adalah pembelajaran matematika dengan menggunakan model quantum teaching dengan pendekatan kontekstual pada pecahan.

Teknik pengumpulan data yang digunakan dalam penelitian ini adalah observasi dan tes hasil belajar siswa. Observasi digunakan untuk mengumpulkan data tentang bagaimana aktivitas siswa, dan partisipasi siswa dengan pembelajaran matematika menggunakan strategi model quantum teaching dengan pendekatan kontekstual. Observer berjumlah 2 orang yaitu 1 orang dari guru teman sejawat dan 1 orang dari peneliti.

Sedangkan tes hasil belajar digunakan untuk mengukur pencapaian siswa dalam pembelajaran pecahan dengan model quantum teaching dengan pendekatan kontekstual, hasil belajar siswa diambil setiap kali 
pertemuan dan post test di setiap siklus, bentuk soal tes yang diberikan berupa uraian dengan nilai maksimal 100 dan nilai minimal 0. Pada siklus 1 pertemuan 1 dan 2 ada 3 soal, dengan skor maksimal 15 untuk pertemuan 1 dan skor maksimal 12 untuk pertemuan 2. Pada siklus II pertemuan 1 dan 2 ada 2 soal, dengan skor maksimal 13 untuk pertemuan 1 dan skor maksimal 15 untuk pertemuan 2. Test akhir siklus I ada 6 soal dengan skor maksimal 19, tes akhir siklus II ada 6 soal dengan skor maksimal 19. Nilai dihitung berdasarkan rumus yang sudah ditentukan.

Hasil penelitian di analisis secara deskriptif kualitatif dalam bentuk persentase untuk melihat aktivitas belajar siswa dalam proses pembelajaran, sedangkan tes hasil belajar dianalisis dengan memberikan skor setiap jawaban, untuk menentukan ketuntasan belajar secara individual dan klasikal.

Penelitian ini dikatakan berhasil apabila seorang siswa dinyatakan tuntas apabila ia telah memenuhi Kriteria Ketuntasan Minimal (KKM) yang di dapat dengan memberikan point pada setiap kriteria yang ditetapkan. KKM yang telah ditetapkan sekolah sebesar $\geq 60,25$ untuk individu yang dikatakan tuntas. Sedangkan untuk ketuntasan klasikal sekolah menetapkan $\geq 80 \%$ dari jumlah seluruh siswa yang tuntas.

Sedangkan partisipasi siswa dalam pembelajaran pada kajian penelitian ini dapat dilihat dari tiga indikator yaitu memberikan pendapat, kerja keras, tanggung jawab dalam pembelajaran dan komunikasi timbal balik. Partisipasi siswa dalam pembelajaran matematika dengan menggunakan model quantum teaching dengan pendekatan kontekstual adalah teknik analisis persentase. Indikator keberhasilan partisipasi siswa dikatakan berhasil bila terdapat siswa yang terlibat dalam pembelajaran $\geq 41 \%$ dan dapat dikualifikasikan cukup tinggi, tinggi, dan sangat tinggi. 
Meningkatkan Hasil Belajar Siswa Menggunakan Model Quantum Teaching Dengan Pendekatan Kontekstual Pokok Bahasan Pecahan Di Kelas V Tunarungu SDLB Negeri Sungai Paring Martapura Tahun Pelajaran 2015/2016

\section{Hasil Penelitian}

\section{Kondisi Awal Penelitian}

Berdasarkan hasil awal dan observasi pembelajaran diperoleh fakta yang menunjukkan bahwa pada proses pembelajaran siswa kurang berminat dalam mengikuti pembelajaran karena menganggap bahwa pelajaran Matematika khususnya pada soal pecahan sangat sulit. Hasil belajar siswa rendah karena penyampaian materi kurang menarik, metode pembelajaran yang tidak relevan serta alat peraga yang sangat terbatas. Akibatnya pada saat dilakukan tes maka anak tidak mampu mengerjakan dengan baik. Setelah memperoleh fakta tersebut peneliti merencanakan studi pembelajaran yang belum dilakukan sebelumnya. Dengan model quantum teaching pada pembelajaran matematika soal cerita pecahan diharapkan kemampuan siswa tunarungu akan meningkat.

\section{Hasil Penelitian Siklus I}

\section{a. Perencanaan dan pelaksanaan}

Berdasarkan rumusan hipotesis yang telah dibuat, peneliti menyiapkan rencana pelaksanaan pembelajaran beserta skenario pembelajaran yang mencakup langkah-langkah yang akan dilakukan guru dan siswa dalam kegiatan pembelajaran. Melaksanakan pembelajaran pada siklus I, maka dilaksanakan persiapan sebagai berikut: menyusun rencana pelaksanaan pembelajaran matematika, standar kompetensi dasar, materi pokok pecahan, serta penggunaannya dalam pemecahan masalah. Menyiapkan bahan pembelajaran berupa RPP, Lembar kerja siswa dan soal test evaluasi. Membuat format observasi tentang kegiatan pembelajaran baik guru maupun kegiatan pembelajaran siswa.

Pada pertemuan pertama guru memulai pelajaran dengan berdoa, mengabsen siswa di mana pada pertemuan ini semua siswa hadir, guru menyampaikan tujuan pembelajaran, memberikan informasi singkat tentang model quantum teaching dengan 
pendekatan kontekstual yang akan dilaksanakan, serta memberikan motivasi, dan melakukan apersepsi tentang materi operasi penjumlahan pecahan serta memberikan kesempatan pada siswa untuk bertanya. Guru memberikan acuan materi kepada siswa dan mempersilahkan siswa untuk memahami acuan materi tersebut. Guru kemudian menjelaskan materi secara klasikal. Suasana pembelajaran di dalam kelas dapat dilihat pada gambar.
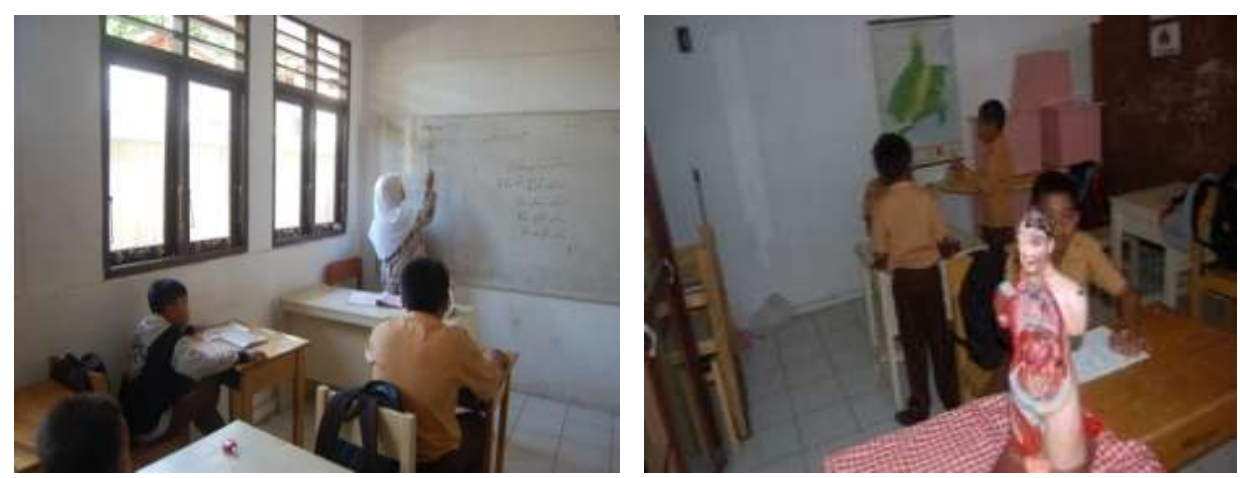

Gambar 1 : Suasana Pembelajaran pada siklus 1 pertemuan 1

Selanjutnya guru memberikan soal evaluasi, kegiatan ini bertujuan untuk mengetahui hasil belajar siswa setelah mengikuti pembelajaran dengan menggunakan model quantum teaching dengan pendekatan kontekstual. Pada akhir pembelajaran, guru bersama siswa menyimpulkan tentang pembelajaran yang telah dipelajari dan meminta siswa mengekspresikan keberhasilan pembelajaran yang telah dilaksanakan. Dan sebagai tindak lanjut guru mengakhiri pelajaran hari ini dengan menginformasikan materi yang akan dibahas pada pertemuan selanjutnya. Guru menutup pelajaran dengan mengucapkan salam.

Pada pertemuan kedua guru memulai pelajaran dengan mengabsen siswa di mana pada pertemuan ini semua siswa hadir, guru menyampaikan tujuan pembelajaran, memberikan informasi singkat tentang model quantum teaching dengan pendekatan kontekstual yang akan dilaksanakan, serta memberikan motivasi dan 
Meningkatkan Hasil Belajar Siswa Menggunakan Model Quantum Teaching Dengan Pendekatan Kontekstual Pokok Bahasan Pecahan Di Kelas V Tunarungu SDLB Negeri Sungai Paring Martapura Tahun Pelajaran 2015/2016

memutarkan musik instrumental, dan melakukan apersepsi tentang materi Operasi penjumlahan pecahan berpenyebut tidak sama serta memberikan kesempatan pada siswa untuk bertanya. Guru memberikan acuan materi kepada siswa dan mempersilakan siswa untuk memahami acuan materi tersebut. Kemudian guru menjelaskan materi secara klasikal. Guru menjelaskan materi operasi penjumlahan berpenyebut sama dapat dilihat pada gambar di atas.

Kegiatan selanjutnya, guru menugasi siswa. Guru memberikan LKS dimana pada lembar kerja siswa sudah diajukan masalah kontekstual yang mengarah pada materi operasi penjumlahan pecahan berpenyebut tidak sama pada masing-masing siswa, guru menyampaikan langkah-langkah pelaksanaan diskusi dan selanjutnya guru meminta siswa berdiskusi untuk mengerjakan soal yang tersedia dan membimbing siswa yang mengalami kesulitan.

Setelah mengerjakan, maka perwakilan dari salah satu siswa mempresentasikan hasil kerjanya, selanjutnya setelah selesai mempresentasikan hasil diskusinya di depan kelas guru meluruskan beberapa jawaban siswa yang kurang tepat dan memberikan kesempatan siswa untuk bertanya, dan siswa diminta kembali ke tempat duduk semula. Guru menjelaskan kembali secara umum mengenai materi yang sedang dipelajari.

Selanjutnya guru memberikan soal evaluasi, kegiatan ini bertujuan untuk mengetahui hasil belajar siswa setelah mengikuti pembelajaran dengan menggunakan model quantum teaching dengan pendekatan kontekstual. Pada akhir pembelajaran, guru bersama siswa menyimpulkan tentang pembelajaran yang telah dipelajari dan meminta siswa mengekspresikan keberhasilan pembelajaran yang telah dilaksanakan. Pada pertemuan berikutnya selama 1 jam pelajaran, siswa diminta mengerjakan soal tes akhir siklus 1 


\section{b. Pengamatan (hasil observasi)}

Hasil observasi aktivitas belajar siswa ialah pengamatan terhadap apa-apa saja dilakukan siswa dalam pengamatan saat kegiatan belajar mengajar berlangsung menggunakan model quantum teaching dengan pendekatan kontekstual pada pertemuan pertama dan kedua di kelas V SDLBN Sungai Paring Martapura yang dapat dilihat dari tabel 1 berikut:

Tabel. 1 Hasil Observasi Aktivitas Siswa Siklus 1

\begin{tabular}{|l|l|l|l|}
\hline \multirow{2}{*}{ Kegiatan } & \multicolumn{2}{|c|}{ Siklus 1 } & Rata-Rata Aktivitas \\
\cline { 2 - 3 } & Pert.1 & Pert.2 & Belajar Siswa \\
\hline Persentase & $71,7 \%$ & $75,7 \%$ & $73,8 \%$ \\
\hline
\end{tabular}

Data hasil penelitian tindakan siklus 1 terdiri dari masingmasing nilai hasil evaluasi setiap kali pertemuan dan nilai tes akhir siklus I dapat dilihat pada tabel 2 berikut:

Tabel 2. Nilai Hasil Belajar Siklus I

\begin{tabular}{|l|l|l|l|}
\hline Hasil Belajar & Pert.1 & Pert.2 & Test Akhir Siklus I \\
\hline Rata-rata & 68,2 & 69,6 & 72,1 \\
\hline Ketuntasan (\%) & 71,4 & 82,1 & 78,5 \\
\hline
\end{tabular}

Hasil observasi tingkat partisipasi siswa yang dilakukan oleh observer dalam pembelajaran operasi pecahan di kelas $V$ SDLB Negeri Sungai Paring Martapura dengan menggunakan model quatum teaching denga pendekatan kontekstual dapat disajikan pada tabel 3 berikut:

Tabel 3. Hasil Observasi Partisipasi Siswa Siklus 1

\begin{tabular}{|l|l|l|l|}
\hline \multirow{2}{*}{ Kegiatan } & \multicolumn{2}{|c|}{ Siklus 1 } & Rata-Rata Partisipasi \\
\cline { 2 - 3 } & Pert.1 & Pert.2 & Siswa \\
\hline Persentase & $56,5 \%$ & $61,3 \%$ & $59,6 \%$ \\
\hline
\end{tabular}

\section{c. Refleksi}

Berdasarkan hasil penelitian siklus I tentang aktivitas belajar siswa, hasil belajar dan partisipasi siswa terhadap pembelajaran 
Meningkatkan Hasil Belajar Siswa Menggunakan Model Quantum Teaching Dengan Pendekatan Kontekstual Pokok Bahasan Pecahan Di Kelas V Tunarungu SDLB Negeri Sungai Paring Martapura Tahun Pelajaran 2015/2016

menggunakan model quantum teaching dengan pendekatan kontekstual dapat direfleksikan sebagai berikut:

1) Aktivitas siswa pada siklus I masih kurang. Hal ini disebabkan siswa masih belum mampu beradaptasi dengan model pembelajaran yang disajikan guru. Terlihat siswa masih banyak yang diam, malu untuk bertanya kepada teman dan guru. Dengan demikian ini akan menjadi perhatian peneliti guna perbaikan pada siklus berikutnya.

2) Hasil belajar siswa belum memenuhi indikator keberhasilan. Hal ini disebabkan siswa belum bisa menguasai materi pembelajaran, belum terbiasanya siswa untuk belajar mandiri dan belajar dengan teman. Hal ini akan menjadi perhatian peneliti dalam mengolah materi yang lebih baik guna perbaikan hasil belajar siswa pada siklus II.

3) Partisipasi siswa pada siklus I masih kurang. Ini disebabkan siswa masih belum mampu beradaptasi dengan model pembelajaran yang disajikan guru. Terlihat masih banyak siswa yang masih belum terlibat secara mental dan emosional dalam kegiatan belajar mengajar. Dengan demikian ini akan menjadi perhatian peneliti guna perbaikan pada siklus berikutnya

\section{Hasil Penelitian Siklus II}

\section{a. Perencanaan dan pelaksanaan}

Kegiatan penelitian tindakan kelas pertemuan ketiga sama halnya pada pertemuan satu dan dua, hanya saja materi yang berbeda yaitu materi lanjutan dari pertemuan satu dan dua (siklus I). Pada pertemuan 3 ini guru menyampaikan materi pelajaran tentang operasi pengurangan pecahan dengan penyebut sama. Guru memulai pelajaran dengan berdoa, mengabsen siswa di mana pada pertemuan ini semua siswa hadir, guru menyampaikan tujuan pembelajaran, memberikan informasi singkat tentang model 
quantum teaching dengan pendekatan kontekstual yang akan dilaksanakan, serta memberikan motivasi dan memutarkan musik instrumental, dan melakukan apersepsi tentang materi operasi pengurangan pecahan berpenyebut sama serta memberikan kesempatan pada siswa untuk bertanya. Guru memberikan acuan materi kepada siswa dan mempersilakan siswa untuk memahami acuan materi tersebut. Kemudian guru menjelaskan materi secara klasikal.

Kegiatan selanjutnya, guru memberikan LKS dimana pada lembar kerja siswa sudah diajukan masalah kontekstual yang mengarah pada materi operasi pengurangan pecahan berpenyebut sama pada masing-masing kelompok, guru menyampaikan langkahlangkah pelaksanaan diskusi dan selanjutnya guru meminta siswa berdiskusi untuk mengerjakan soal yang tersedia dan membimbing siswa yang mengalami kesulitan. Setelah selesai mengerjakan, maka perwakilan dari salah satu siswa mempresentasikan hasil kerja kelompoknya. Salah satu siswa mempresentasikan hasil kerjanya dapat dilihat pada gambar di bawah ini.

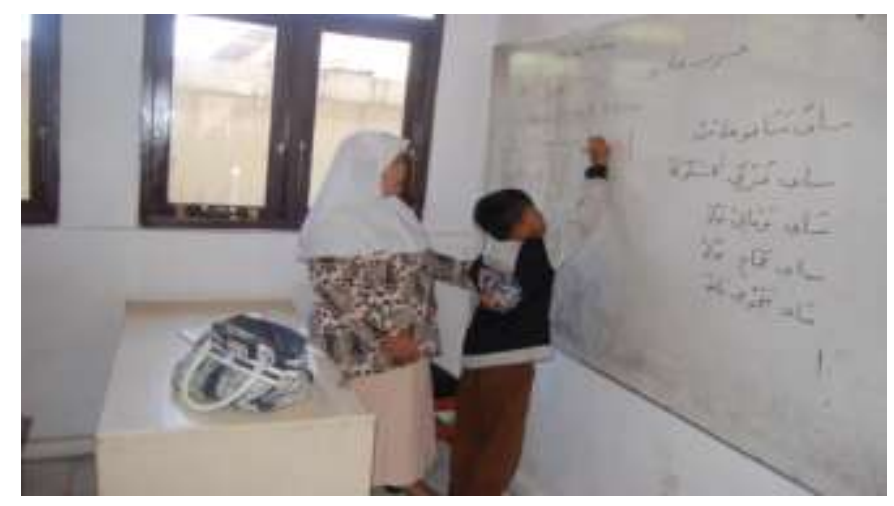

Gambar 2. Siswa mempresentasikan hasil kerja pada siklus II

Selanjutnya setelah selesai mempresentasikan hasil diskusinya di depan kelas guru meluruskan beberapa jawaban siswa yang kurang tepat dan memberikan kesempatan siswa untuk bertanya, dan siswa diminta kembali ke tempat duduk semula. Guru 
Meningkatkan Hasil Belajar Siswa Menggunakan Model Quantum Teaching Dengan Pendekatan Kontekstual Pokok Bahasan Pecahan Di Kelas V Tunarungu SDLB Negeri Sungai Paring Martapura Tahun Pelajaran 2015/2016

menjelaskan kembali secara umum mengenai materi yang sedang dipelajari. Selanjutnya guru memberikan soal evaluasi, kegiatan ini bertujuan untuk mengetahui hasil belajar siswa setelah mengikuti pembelajaran dengan menggunakan model quantum teaching dengan pendekatan kontekstual. Pada akhir pembelajaran, guru bersama siswa menyimpulkan tentang pembelajaran yang telah dipelajari dan meminta siswa mengekspresikan keberhasilan pembelajaran yang telah dilaksanakan. Dan sebagai tindak lanjut guru mengakhiri pelajaran hari ini dengan menginformasikan materi yang akan dibahas pada pertemuan selanjutnya. Guru menutup pelajaran dengan mengucapkan salam.

Pada pertemuan ke empat seperti pada pertemuan sebelumnya guru memulai pelajaran dengan mengabsen siswa di mana pada pertemuan ini semua siswa hadir, guru memulai pelajaran dengan berdoa, mengabsen siswa di mana pada pertemuan keekmpat ini semua siswa hadir, guru menyampaikan tujuan pembelajaran, memberikan informasi singkat tentang model quantum teaching dengan pendekatan kontekstual yang akan dilaksanakan, serta memberikan motivasi dan memutarkan musik instrumental, dan melakukan apersepsi tentang materi operasi pengurangan pecahan berpenyebut sama serta memberikan kesempatan pada siswa untuk bertanya. Guru memberikan acuan materi kepada siswa dan mempersilakan siswa untuk memahami acuan materi tersebut. Kemudian guru menjelaskan materi secara klasikal. Seperti pada petemuan satu, dua, dan tiga pada pertemuan keempat ini guru memberikan LKS dimana pada lembar kerja siswa sudah diajukan masalah kontekstual yang mengarah pada materi operasi pengurangan pecahan berpenyebut tidak sama pada masingmasing kelompok, guru menyampaikan langkah-langkah pelaksanaan diskusi dan selanjutnya guru meminta siswa berdiskusi untuk mengerjakan soal yang tersedia dan membimbing siswa yang 
mengalami kesulitan. Guru membimbing siswa yang mengalami kesulitan.

Setelah selesai mengerjakan, maka perwakilan dari salah satu siswa mempresentasikan hasil kerjanya, selesai mempresentasikan hasil diskusinya didepan kelas guru meluruskan beberapa jawaban siswa yang kurang tepat dan memberikan kesempatan siswa untuk bertanya, dan siswa diminta kembali ke tempat duduk semula. Guru menjelaskan kembali secara umum mengenai materi yang sedang dipelajari. Selanjutnya guru memberikan soal evaluasi, kegiatan ini bertujuan untuk mengetahui hasil belajar siswa setelah mengikuti pembelajaran dengan menggunakan model quantum teaching dengan pendekatan kontekstual. Pada akhir pembelajaran, guru bersama siswa menyimpulkan tentang pembelajaran yang telah dipelajari dan meminta siswa mengekspresikan keberhasilan pembelajaran yang telah dilaksanakan. Dan guru menutup pelajaran dengan mengucapkan salam. Dan ada pertemuan berikutnya selama 1 jam pelajaran, siswa diminta mengerjakan soal tes akhir siklus II.

\section{b. Pengamatan (hasil observasi)}

Hasil observasi aktivitas siswa ialah pengamatan terhadap apa-apa saja dilakukan siswa dalam pengamatan saat kegiatan belajar mengajar berlangsung menggunakan model quantum teaching dengan pendekatan kontekstual pada pertemuan ketiga dan keempat di kelas V SDLBN Sungai Paring Martapura yang dapat dilihat dari tabel berikut:

Tabel 4. Hasil Observasi Aktivitas Siswa Siklus II

\begin{tabular}{|l|l|l|l|}
\hline \multirow{2}{*}{ Kegiatan } & \multicolumn{2}{|c|}{ Siklus II } & \multirow{2}{*}{$\begin{array}{c}\text { Rata-Rata Aktivitas } \\
\text { Belajar Siswa }\end{array}$} \\
\cline { 2 - 3 } & Pert.1 & Pert.2 & $82,1 \%$ \\
\hline Persentase & $79,8 \%$ & $84,6 \%$ & 82,0 \\
\hline
\end{tabular}

Data hasil penelitian tindakan siklus II terdiri dari masingmasing nilai hasil evaluasi setiap kali pertemuan dan nilai tes akhir siklus II dapat dilihat pada tabel 5 berikut: 
Meningkatkan Hasil Belajar Siswa Menggunakan Model Quantum Teaching Dengan Pendekatan Kontekstual Pokok Bahasan Pecahan Di Kelas V Tunarungu SDLB Negeri Sungai Paring Martapura Tahun Pelajaran 2015/2016

Tabel 5. Nilai Hasil Belajar Siklus II

\begin{tabular}{|l|c|c|c|}
\hline Hasil Belajar & Pert.1 & Pert.2 & Test Akhir Siklus II \\
\hline Rata-rata & 75,5 & 79,2 & 82,1 \\
\hline Ketuntasan (\%) & 100 & 100 & 100 \\
\hline
\end{tabular}

Hasil oservasi tingkat partisipasi siswa yang dilakukan oleh observer dalam pembelajaran pecahan di kelas $V$ SDLBN Sungai Paring Martapura dengan menggunakan model quatum teaching denga pendekatan kontekstual dapat disajikan pada tabel 6 berikut:

Tabel 6. Hasil Observasi Partisipasi Siswa Siklus II

\begin{tabular}{|l|c|c|c|}
\hline \multirow{2}{*}{ Kegiatan } & \multicolumn{2}{|c|}{ Siklus 2 } & \multirow{2}{*}{$\begin{array}{c}\text { Rata-Rata } \\
\text { Partisipasi Siswa }\end{array}$} \\
\cline { 2 - 3 } & Pert.1 & Pert.2 & $68,8 \%$ \\
\hline Persentase & $62,7 \%$ & $75,2 \%$ & 6 \\
\hline
\end{tabular}

\section{c. Refleksi}

Berdasarkan hasil penelitian siklus II tentang aktivitas siswa, hasil belajar siswa, aktivitas guru dan partisipasi siswa terhadap pembelajaran menggunakan model quantum teaching dengan pendekatan kontekstual dapat direfleksikan sebagai berikut:

1) Aktivitas belajar siswa pada siklus II meningkat, dimana sudah banyak siswa yang mulai terbiasa dengan model pembelajaran yang ditetapkan oleh guru dan semakin bersemangat untuk mengikuti pembelajaran. Dengan demikian penelitian ini ditinjau dari segi aktivitas siswa sudah berhasil.

2) Peningkatan hasil belajar siswa sudah memenuhi indikator keberhasilan. Hal ini disebabkan siswa memahami dengan baik pembelajaran yang disajikan guru, sehingga secara perlahan kelemahan pada siklus I dapat diatasi oleh siswa.

3) Partisipasi siswa pada siklus II meningkat dimana sudah banyak siswa yang terlibat secara mental dan emosional dalam kegiatan pembelajaran. Dengan demikian penelitian ini dikatakan berhasil. 


\section{Pembahasan}

Pembahasan berikut adalah menguraikan mengenai aktivitas belajar siswa, hasil belajar, dan partisipasi siswa yang diolah berdasarkan data hasil penelitian.

\section{Aktivitas belajar siswa}

Hasil observasi aktivitas belajar siswa yang dilakukan oleh observer dalam pembelajaran dengan menggunakan model quantum teaching dengan pendekatan kontekstual pada pembelajaran pecahan pada siswa kelas V SDLBN Sungai Paring Martapura Kabupaten Banjar dapat disajikan pada tabel berikut:

Tabel 7. Perbandingan Aktivitas Siswa Siklus I dan Siklus II

\begin{tabular}{|l|c|c|}
\hline Kegiatan & Siklus 1 & Siklus 2 \\
\hline Aktivitas siswa & $73,8 \%$ & $82,1 \%$ \\
\hline
\end{tabular}

Berdasarkan data pada tabel aktivitas siswa baik siklus I dan siklus II dapat disajikan pada grafik berikut:

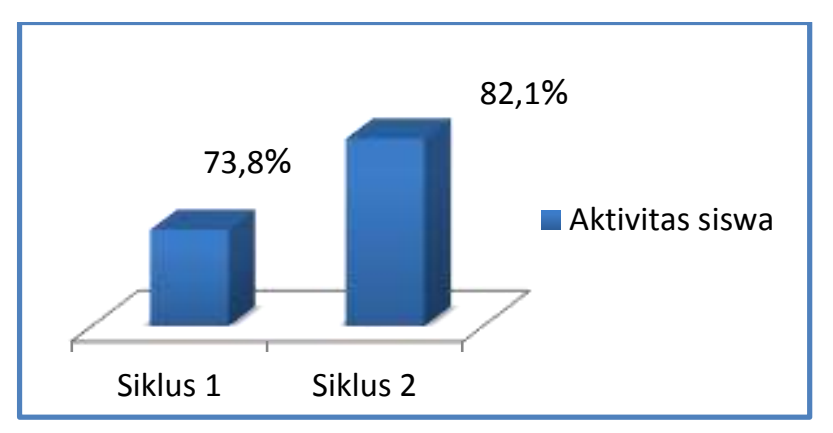

Gambar 3. Grafik Perbandingan aktivitas siswa Siklus I dan Siklus II

Dari hasil penelitian yang diperoleh selama proses belajar mengajar di kelas berlangsung dalam pembelajaran dengan menggunakan model quantum teaching dengan pendekatan kontekstual pada pembelajaran pecahan pada siswa kelas $V$ SDLBN Sungai Paring Martapura, aktivitas siswa meningkat ditunjukkan dengan kenaikan jumlah persentase pada aktivitas siswa dari siklus I ke siklus II. Dari persentase $73,8 \%$ di siklus I dengan kategori baik menjadi $82,1 \%$ dengan kategori baik sekali di siklus II. Dari hasil aktivitas siswa terhadap 
Meningkatkan Hasil Belajar Siswa Menggunakan Model Quantum Teaching Dengan Pendekatan Kontekstual Pokok Bahasan Pecahan Di Kelas V Tunarungu SDLB Negeri Sungai Paring Martapura Tahun Pelajaran 2015/2016

model quantum teaching dengan pendekatan kontekstual ini, dapat dikatakan bahwa siswa merasa lebih senang terhadap model pembelajaran tersebut karena model pembelajaran ini merupakan model pembelajaran yang baru bagi mereka yang berbeda dengan model pembelajaran yang biasanya digunakan sebelumnya. Meskipun pada awalnya beberapa siswa mungkin masih banyak yang diam dan malu untuk bertanya kepada teman dan guru, namun lama kelamaan mereka mulai terbiasa dan semakin bersemangat untuk mengikuti pembelajaran. Siswa juga lebih mudah memahami materi dan mendapatkan peningkatan terhadap pemahaman dari materi yang ada. Sesuai dengan apa yang dikatakan Depoter dalam bukunya yang berjudul quantum teaching, quantum teaching itu sendiri adalah pengubahan bermacam-macam interaksi yang berada di dalam dan di sekitar momen belajar. Jadi quantum teaching dengan pendekatan kontekstual menciptakan lingkungan belajar yang efektif, dengan cara menggunakan unsur yang ada pada siswa dan lingkungan belajarnya serta mengaitkanya dengan pengalaman di kehidupan nyata melalui interaksi yang terjadi di dalam kelas. Sehingga penggunaan model quantum teaching dengan pendekatan kontekstual dapat meningkatkan aktivitas siswa.

\section{Hasil belajar siswa}

Data yang diperoleh berdasarkan tes hasil belajar pada materi pecahan matematika baik siklus I dan siklus II dapat disajikan pada tabel 8 di bawah ini.

Tabel 8. Perbandingan Hasil Belajar Siklus I dan Siklus II

\begin{tabular}{|l|c|c|}
\hline Hasil Belajar & Siklus I & Siklus II \\
\hline Rata-rata & 72,1 & 82,1 \\
\hline Ketuntasan (\%) & 78,5 & 100 \\
\hline
\end{tabular}

Berdasarkan tabel di atas dapat disajikan dalam bentuk grafik berikut: 


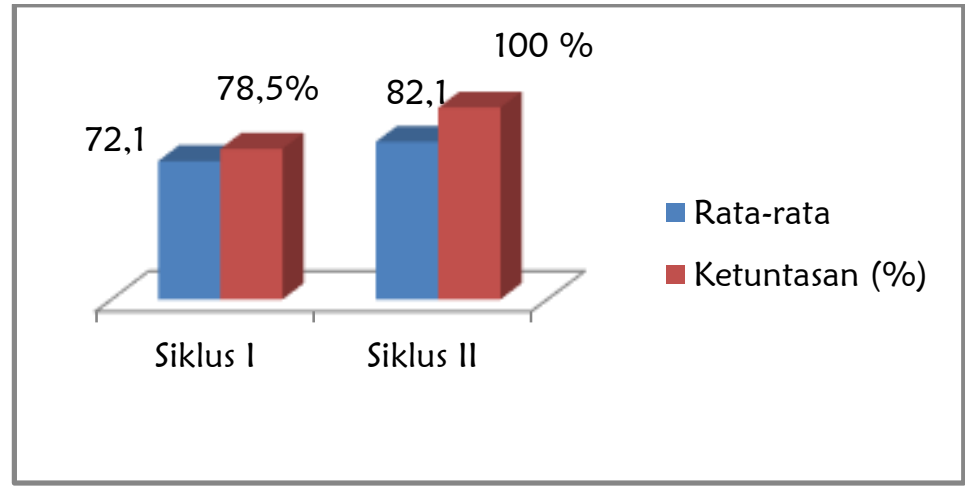

Gambar 4. Grafik Perbandingan Hasil Belajar Siklus I dan Siklus II

Berdasarkan data nilai hasil belajar siswa kelas V SDLBN Sungai Paring Martapura pada siklus I mengenai hasil belajar siswa terjadi peningkatan dari rata-rata 72,1 dengan ketuntasan klasikal 78,5\% dan pada siklus II mengalami peningkatan menjadi rata-rata 82,1 dengan ketuntasan klasikal 100\%. Data yang diperoleh pada siklus II sudah memenuhi indikator keberhasilan. Dengan demikian penelitian tindakan kelas dikatakan berhasil. Hal ini disebabkan siswa memahami dengan baik pembelajaran yang menggunakan model quantum teaching dengan pendekatan kontekstual yang disajikan oleh guru, sehingga secara perlahan kelemahan pada siklus I dapat diatasi siswa.

Model quantum teaching adalah suatu model pembelajaran yang memunculkan kemampuan berpikir dengan menggunakan otak kiri dan otak kanan yang dapat menciptakan lingkungan belajar menjadi lebih efektif. Otak kiri menangani angka, susunan, logika, organisasi, dan hal lain yang memerlukan pemikiran rasional, beralasan dengan pertimbangan yang deduktif dan analitis. Otak kanan mengurusi masalah pemikiran yang abstrak dengan penuh imajinasi, sehingga quantum teaching dapat menciptakan suasan belajar lebih nyaman yang akan memudahkan proses belajar. Hal ini hal ini sesuai dengan apa yang dikatakan oleh Vos Groenedal bahwa murid-murid yang mengikuti pembelajaran dengan mengguankan quantum teaching di SuperCamp 
Meningkatkan Hasil Belajar Siswa Menggunakan Model Quantum Teaching Dengan Pendekatan Kontekstual Pokok Bahasan Pecahan Di Kelas V Tunarungu SDLB Negeri Sungai Paring Martapura Tahun Pelajaran 2015/2016

mendapatkan nilai yang lebih baik, lebih banyak berpartisipasi dan lebih bangga akan dirinya sendiri (Doporter, 2002:4)

\section{Partisipasi siswa}

Hasil observasi partisipasi siswa yang dilakukan oleh observer dalam pembelajaran dengan menggunakan model quantum teaching dengan pendekatan kontekstual pada pembelajaran pecahan pada siswa kelas V SDLBN Sungai Paring Martapura dapat disajikan pada tabel 9 berikut:

Tabel 9. Perbandingan Partisipasi Siswa Siklus I dan Siklus II

\begin{tabular}{|l|c|c|}
\hline Kegiatan & Siklus 1 & Siklus 2 \\
\hline Partisipasi siswa & $59,6 \%$ & $68,8 \%$ \\
\hline
\end{tabular}

Berdasarkan data pada tabel partisipasi siswa baik siklus I dan siklus II dapat disajikan pada grafik berikut

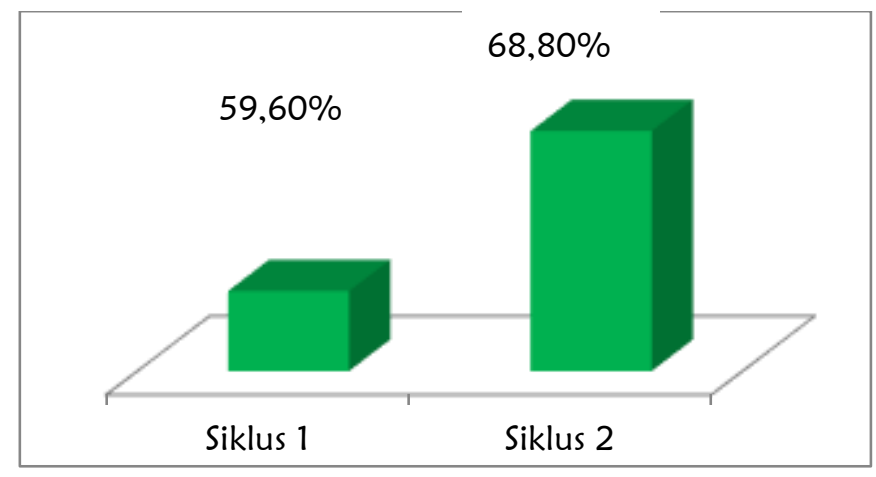

Gambar 5. Grafik Perbandingan Partisipasi Siklus I dan Siklus II

Dari hasil penelitian yang diperoleh selama proses belajar mengajar di kelas berlangsung, partisipasi siswa mengalami peningkatan dari siklus I ke siklus II. Partisipasi siswa dari siklus I dengan persentase $59,6 \%$ sudah dalam kategori cukup. Hal ini dikarenakan siswa merasa antusias dan senang selama proses pembelajaran berlangsung. Kemudian pada siklus II tingkat partisipasi siswa mengalami peningkatan menjadi $68,8 \%$ kategori baik, disebabkan siswa lebih antusias dan aktif dalam merespon apa yang disampaikan oleh guru. 
Pembelajaran menggunakan model quantum teaching dengan pendekatan kontekstual dapat memotivasi siswa, memberi semangat, kegembiraan dan menumbuhkan rasa senang dalam belajar matematika. Sangat terlihat adanya keterlibatan emosional juga mental siswa terhadap pembelajaran yang sedang berlangsung. Selama proses pembelajaran berlangsung siswa antusias dan mengikuti pembelajaran dengan baik. Dalam quantum teaching bersandar pada konsep 'Bawalah dunia mereka ke dunia kita, dan antarkan dunia kita ke dunia mereka' (Deporter, 2002:7). Hal ini menunjukkan, betapa pengajaran dengan quantum teaching tidak hanya menawarkan materi yang mesti dipelajari siswa. Tetapi jauh dari itu, siswa juga diajarkan bagaimana menciptakan hubungan emosional dan mental yang baik dalam dan ketika belajar. Sehingga penggunaan model quantum teaching dengan pendekatan kontekstual dapat meningkatkan partisipasi siswa.

\section{Kesimpulan}

Berdasarkan hasil penelitian dan pembahasan serta analisis data yang diperoleh melalui penelitian tindakan kelas pada materi operasi pecahan matematika menggunakan model quantum teaching dengan pendekatan kontestual pada siswa kelas V SDLBN Sungai Paring Martapuradapat disimpulkan sebagai berikut:

1. Penggunaan model quantum teaching dengan pendekatan kontestual dapat meningkatkan aktivitas siswa dari siklus I dengan kategori baik, mengalami peningkatan pada siklus II dengan kategori baik sekali.

2. Penggunaan model quantum teaching dengan pendekatan kontestual dapat meningkatkan hasil belajar siswa dari rata-rata 72,1 dengan ketuntasan klasikal sebesar 78,5\% pada siklus I menjadi 82,1 dengan ketuntasan klasikal 100\% pada siklus II.

3. Penggunaan model quantum teaching dapat meningkatkan partisipasi siswa dari siklus I dengan kategori cukup, mengalami peningkatan pada siklus II dengan kategori baik. 
Meningkatkan Hasil Belajar Siswa Menggunakan Model Quantum Teaching Dengan Pendekatan Kontekstual Pokok Bahasan Pecahan Di Kelas V Tunarungu SDLB Negeri Sungai Paring Martapura Tahun Pelajaran 2015/2016

\section{Daftar Pustaka}

Arikunto, dkk. 2011. Penelitian Tindakan Kelas Jakarta: Bumi Aksara.

Arikunto, S. 2011. Dasar-Dasar Evaluasi Pendidikan. Edisi Revisi. Jakarta : PT. Bumi Aksara.

Bobbi Depotter, Mark Reardon, dan Sarah Singer Nourie. 2002. Quantum Teaching. Bandung : Kaifa.

Depdiknas, 2006. Undang-Undang Republik Indonesia Nomor 20 tahun 2003 Tentang Sistem Pendidikan. Jakarta: Sekjen Depdinas.

Evi, dkk. 2010. Buku panduan Pendidikan Matematika untuk SD dan MI Intan Pariwara. KALTENG : PT Manacana Jaya Cemerlang.

Ekodjatmiko, 2006. Pedoman Administrasi Sekolah Dasar Luar Biasa, Direktorat Peminaan Sekolah Luar Biasa.

Gatot Muhsetyo, 2007. Materi Pokok Pembelajaran Matetaika SD ; Modul 1-9/PDGK4406. Edisi I, Jakarta: Universitas Terbuka.

Hasan Fauzi Maufur, 2009 . Sejuta Jurus mengasikan. Semarang : PT Sindur Press.

Kunandar, 2008. Langkah Mudah Penelitian Tindakan Kelas Sebagai Pengembanagan Profesi Guru. Jakarta: PT Raja Grafindo Persada.

Ridwan, 2010. Belajar Mudah Penelitian untuk Guru-Karyawan dan Peneliti Pemula. Bandung : Alfabeta.

Slameto, 2010. Belajar dan Faktor-Faktor yang Mempengaruhinya. Bandung : Remaja Rosdakarya.

Sudjana, N. 2009. Penilaian Hasil Proses Belajar Mengajar. Jakarta : Sinar Baru Algensindo.

Sudijono, Anas. 2010. Pengantar Statistik Pendidikan. Jakarta: Rajawali Pers.

Susilo. 2009. Panduan Penelitian Tindakan Kelas. Yogyakarta : Pustaka Book Publisher.

Sugiyono, 2006. Metode Penelitian Pendidikan Pendekatan Kuantitatif, Kualitatif dan $R \& D$. Bandung : Alfabeta. 
Purwanti

Trianto, 2010. Mendesain Model Pembelajaran Inovatif-Progresif: Konsep, Landasan, dan Implementasinya pada Kurikulum Tingkat Satuan Pendidikan(KTSP). Jakarta : Kencana.

\section{Purwanti}

SDLN Negeri Sungai Paring Martapura

E-mail: Purwanti.sdlb@gmail.com 